\title{
Analysis of Students' Understanding of Mathematical Concepts in Solving Comparative Problems
}

\author{
Hafifah Debby Puspithasari ${ }^{*}$, Heni Pujiastuti ${ }^{2}$ \\ ${ }^{1,2}$ Universitas Sultan Ageng Tirtayasa \\ *hafifahdebby1711@gmail.com
}

Received: May 2020; Accepted: December 2020; Published: January 2021

\begin{abstract}
The purpose of this study is to analyze the students' concept and students' mistake while solving the Comparison task. This experiment used the qualitative descriptive methode. The Subjects of this experiment were the students in Daan Mogot Junior High School grade. Data were collected by observation method. The result shows that the percentage of students' concept understanding while solving the Comparison is $67,18 \%$, the result of object clarification according to another character is $37,69 \%$, giving sample and non sample is 99,04\%, presenting concept by the right form mathematic representation is $90,38 \%$, developing the need-qualification and enough-qualification concept is $14,1 \%$, using the benefit and chosing the certain procedure is $73,46 \%$ and applying concept and algorithm to solve problem is $41,15 \%$. The students' mistakes while solving the Comparison task are: conceptual mistake, calculation mistake, using the wrong logic to draw the conclusion, using the wrong theorem, not checking the task. Some indicators such as: the students don't understand enough about the abstract question, conceptual proof, how to start the proof, they get difficulties to remember the definition in conceptual proofing and use them to construct the proof, the students are not paying attention while reading the question, and they are having less confidence to answer the questions are the causes of the students' mistake while solving Comparison.
\end{abstract}

Keyword: conceptual understanding, students' mistake, comparison.

How to cite: Puspithasari, H. D. \& Pujiastuti, H. (2021). Analysis of Students' Understanding of Mathematical Concepts in Solving Comparative Problems. Journal of Medives: Journal of Mathematics Education IKIP Veteran Semarang, 5(1), 181-188. 


\section{PENDAHULUAN}

Pendidikan di Indonesia bertuju-an untuk mengembangkan potensi peserta didik agar memiliki kecerdasan, akhlak mulia, dan keterampilan yang diperlukan (Kesumawati, 2016). Dalam Kurikulum Tingkat Satuan Pendidikan (KTSP), dijelaskan bahwa salah satu tujuan pembelajaran matematika adalah agar siswa memiliki kemampuan memecahkan masalah. Usaha pemecahan masalah matematika harus didasari dari pemahaman konsep matematika. Berdasarkan penjelasan di atas maka pemahaman konsep perlu ditanamkan kepada peserta didik sejak dini yaitu sejak anak tersebut masih duduk di bangku sekolah dasar (Karunia \& Mulyono, 2016). Pemahaman merupakan terjemahan dari istilah understanding yang diartikan sebagai penyerapan arti suatu materi yang dipelajari. Dalam Kamus Besar Bahasa Indonesia (KBBI), paham berarti mengerti dengan tepat, sedangkan konsep berarti suatu rancangan. Sedangkan dalam matematika, konsep adalah suatu ide abstrak yang memungkinkan seseorang untuk menggolongkan suatu objek atau kejadian (Purnomo, 2018). Jadi, pemahaman konsep adalah pengertian yang benar tentang suatu rancangan atau ide abstrak.

Pemahaman konsep adalah salah satu aspek penilaian dalam pembelajaran. Penilaian pada aspek pemahaman konsep bertujuan untuk mengetahui sejauh mana kemampuan siswa menerima dan memahami konsep dasar matematika yang telah diterima siswa dalam pembelajaran (Nastiti \& Syaifudin, 2020). Pemahaman konsep sangatlah penting karena dengan menguasai konsep dapat lebih mudah dalam belajar matematika.

Pemahaman konsep adalah proses individu menguasai dengan cara menerima dan memahami informasi yang diperoleh dari pembelajaran yang dilihat melalui kemampuan bersikap, berpikir dan bertindak yang ditunjukkan oleh siswa dalam memahami definisi, pengertian, ciri khusus, hakikat dan inti atau isi dari materi matematika dan kemampuan dalam memilih serta menggunakan prosedur secara efisien dan tepat (I. K. A. Afifah \& Sopiany, 2017).

Pemahaman konsep adalah tingkat kemampuan yang mengharapkan siswa mampu memahami konsep, situasi, dan fakta yang diketahui, serta dapat menjelaskan dengan kata-kata sendiri sesuai dengan pengetahuan yang dimilikinya, tanpa mengubah artinya. Kemampuan pemahaman konsep sangatlah penting, karena dalam matematika konsep satu dengan konsep lainnya memiliki hubungan yang erat (Tanjung \& Herawati, 2020). Jadi dapat disimpulakn bahwa kemampuan pemahaman konsep matematika sangat penting karena di samping menjadi salah satu tujuan pembelajaran matematika, kemampun pemahaman konsep juga dapat membantu siswa untuk tidak hanya sekedar menghafal rumus, tetapi dapat mengerti benar apa makna dalam pembelajaran matematika.

Pemahaman konsep matematika yang diteliti dalam penelitian ini merupakan indikator kemampuan pemahaman konsep matematika yang dirujuk berdasarkan kemampuan pemahaman konsep matematika pada kurikulum 2006. Adapun indikator 
kemampuan pemahaman konsep matematika tersebut antara lain: (1) menyatakan ulang sebuah konsep, yaitu kemampuan untuk mengungkapkan kembali apa yang telah dikomunikasikan, (2) mengklasifikasikan objek-objek menurut sifat-sifat tertentu (sesuai dengan konsepnya), yaitu kemampuan untuk dapat mengelompokkan objek menurut sifat-sifatnya, (3) memberikan contoh dan non contoh dari konsep, yatu kemampuan membedakan contoh dan bukan contoh dari suatu materi yang telah dipelajari, (4) menyajikan konsep dalam berbagai bentuk representasi matematis, yaitu kemampuan menggambar atau membuat grafik, membuat ekspresi matematis, menyusun cerita atau teks tertulis, (5) mrngrmbngkan syarat perlu atau syarat cukup suatu konsep, yaitu kemampuan mengkaji mana syarat perlu atau cukup suatu konsep yang terkait, (6) menggunakan, memanfaatkan, dan memilih prosedur atau operasi tertentu, yaitu kemampuan menyelesaikan soal dengan tepat sesuai dengan prosedur, (7) mengaplikasikan konsep atau algoritma pemecahan masalah, yaitu kemampuan menggunakan konsep serta prosedur dalam menyelesaikan masalah yang berkaitan dengan kehidupan sehari-hari (Fadlilah, 2015).

Adapun rumusan masalah yang dapat diambil dari hal tersebut antara lain bagaimanakah analisis kemampuan pemahaman konsep matematis siswa pada materi perbandingan siswa SMP?

\section{METODE PENELITIAN}

Pendekatan penelitian ini adalah campuran yaitu kuantitatif deskriptif yang bertujuan dalam menganalisis kemampuan pemahaman konsep matematis dalam materi perbandingan pada siswa SMP. Tujuan pembelajaran sendiri dapat menjadi acuan bagi guru dalam mengetahui bagaimana kemampuan pemahaman konsep siswa terhadap materi perbandingan. Penelitian ini adalah penelitian eksperimen dengan jenis penelitiannya adalah quasi eksperiment (eksperimen semu). Sebab sampel yang digunakan telah terbentuk sebelumnya. Pemilihan sampel nya yaitu dengan menggunakan purposive sampling. Metode ini menggunakan kriteria yang telah dipilih oleh peneliti dalam memilih sampel. Kriteria pemilihan sampel terbagi menjadi kriteria inklusi dan eksklusi. Kriteria inklusi merupakan kriteria sampel yang diinginkan peneliti berdasarkan tujuan penelitian. Sedangkan kriteria eksklusi merupakan kriteria khusus yang menyebabkan calon responden yang memenuhi kriteria inklusi harus dikeluarkan dari kelompok penelitian. Misalnya, calon responden mengalami penyakit penyerta atau gangguan psikologis yang dapat memengaruhi hasil penelitian. Penelitian ini ditujukan untuk siswa Sekolah Menengah Pertama (SMP) yang telah menerima atau sedang menerima pembelajaran materi perbandingan. Dan diajukan kepada 3 kategori siswa yaitu siswa dengan kemampuan pemahaman konsep rendah, kemampuan pemahaman konsep sedang, dan kemampuan pemahaman konsep tinggi.

Instrumen dalam penelitian ini antara lain tes. Instrumen tes berupa uraian yang berjumlah 6 soal, bertujuan untuk mendapat data kemampuan 
pemahaman konsep matematika. Tes dibuat berdasarkan indikator pemahaman konsep matematika, yakni: (1) menyatakan ulang sebuah konsep, (2) mengklasifikasikan objek-objek menurut sifat-sifat tertentu (sesuai dengan konsepnya), (3) memberikan contoh dan non contoh dari konsep, (4) menyajikan konsep dalam berbagai bentuk representasi matematis, (5) mengembngkan syarat perlu atau syarat cukup suatu konsep, (6) menggunakan, memanfaatkan, dan memilih prosedur atau operasi tertentu, (7) mengaplikasikan konsep atau algoritma pemecahan masalah (Fadlilah, 2015).

\section{HASIL DAN PEMBAHASAN}

Rata-rata kemampuan pemahaman konsep matematika siswa kelas 7 SMP Daan Mogot Tangerang Tahun Pelajaran 2019/2020 adalah 71,5 sebesar 59,59\% termasuk dalam kategori cukup. Rincian untuk setiap indikator kemampuan pemahaman konsep matematika dapat dilihat pada Tabel 1.

Pada indikator ke-1 yakni, menyatakan ulang sebuah konsep, persentase rata-rata nilainya yaitu $67,18 \%$ termasuk ke dalam kategori baik. Hal ini disebabkan siswa telah paham dengan definisi suatu materi, sehingga siswa dapat menentukan apakah sebuah pernyataan dari suatu soal salah atau benar serta memberikan alasannya jika pernyataan tersebut salah. Meskipun berada dalam kategori baik, namun masih terdapat siswa yang terkendala dalam melakukan pembuktian. Seperti halnya siswa terkadang merasa kebingungan dalam melakukan pembuktian harus dimulai dari mana terlebih dahulu.
Tabel 1. Rata-Rata (dalam Persen) Kemampuan

Pemahaman Konsep Matematis dalam

Menyelesaikan Soal Perbandingan Siswa SMP

\begin{tabular}{|c|c|c|c|}
\hline No. & Indikator & $\begin{array}{l}\text { Persen- } \\
\text { tase }\end{array}$ & $\begin{array}{l}\text { Kate- } \\
\text { gori }\end{array}$ \\
\hline 1 & $\begin{array}{l}\text { Menyatakan ulang sebuah } \\
\text { konsep }\end{array}$ & $67,18 \%$ & Baik \\
\hline 2 & $\begin{array}{l}\text { Mengklasifikasikan objek- } \\
\text { objek menurut sifat-sifat } \\
\text { tertentu }\end{array}$ & $37,69 \%$ & Kurang \\
\hline 3 & $\begin{array}{l}\text { Memberikan contoh dan } \\
\text { non contoh dari konsep }\end{array}$ & $99,04 \%$ & $\begin{array}{c}\text { Sangat } \\
\text { Baik }\end{array}$ \\
\hline 4 & $\begin{array}{l}\text { Menyajikan konsep dalam } \\
\text { berbagai bentuk represen- } \\
\text { tasi matematis }\end{array}$ & $90,38 \%$ & $\begin{array}{c}\text { Sangat } \\
\text { Baik }\end{array}$ \\
\hline 5 & $\begin{array}{l}\text { Mengembangkan syarat } \\
\text { perlu atau syarat cukup } \\
\text { suatu konsep }\end{array}$ & $14,1 \%$ & $\begin{array}{l}\text { Kurang } \\
\text { Sekali }\end{array}$ \\
\hline 6 & $\begin{array}{l}\text { Menggunakan, memanfaat- } \\
\text { kan, dan memilih prosedur } \\
\text { atau operasi tertentu }\end{array}$ & $73,46 \%$ & Baik \\
\hline 7 & $\begin{array}{l}\text { Mengaplikasikan konsep } \\
\text { atau algoritma pemecahan } \\
\text { masalah }\end{array}$ & $41,15 \%$ & Cukup \\
\hline
\end{tabular}

Hal ini ditemukan bahwa kesulitan siswa dalam menyusun bukti disebabkan oleh siswa yang tidak tahu cara mengawali pembuktian. Siswa sudah paham dengan definisi perbandingan, namun siswa kurang memahami soal dengan baik. Akhirnya siswa kurang tepat dalam menentukan sebuah pernyataaan. Siswa kurang memahami sifat-sifat dari perbandingan. Akibatnya siswa kurang tepat dalam mengambil kesimpulan. Siswa sudah paham tentang konsep perbandingan, namun siswa kebingunan dalam mengambil kesimpulan. Oleh karena itu, dibutuhkan sebuah pemahaman konsep yang bagus terhadap suatu definisi untuk dapat melakukan sebuah pembuktian secara runtut dan tepat agar dapat menjawab sebuah pernyataan dengan tepat dan benar. Kebingungan dengan pembuktian tidak hanya dalam memulai pembuktian tetapi juga dalam membaca bukti orang lain. 
Pada indikator ke-2, yakni mengklasifikasikan objek-objek menurut sifat-sifat tertentu, persentase untuk ratarata nilainya yaitu $37,69 \%$ termasuk dalam kategori kurang. Hal ini disebabkan siswa belum dapat mengklasifikasi apakah suatu perbandingan merupakan perbandingan senilai atau perbandingan berbalik nilai. Karena untuk mengklasifikasi suatu perbandingan, mereka memerlukan langkah pembuktian terlebih dahulu. Hal ditemukan bahwa gambaran konsep yang dimiliki oleh siswa tidak memadai untuk menyusun suatu pembuktian. Siswa tidak memahami aturan sesuai dengan soal yang sudah ditentukan. Akibatnya siswa kesulitan dalam melakukan pembuktian, sehingga siswa tidak dapat menjawab pertanyaan tersebut dengan tepat. Oleh karena itu, untuk dapat menjawab pertanyaan tersebut dibutuhkan pemahaman tentang syarat sebuah perbandingan merupakan perbandingan senilai ataupun perbandingan berbalik nilai dan kemudian melakukan pembuktian dengan runtut dan tepat agar dapat menjawab pertanyaan tersebut dengan tepat.

Pada indikator ke-3, yakni memberikan contoh dan non contoh dari konsep, besar persentase untuk rata-rata nilainya yaitu $99,04 \%$ termasuk dalam kategori sangat baik. Hal ini disebabkan siswa sudah paham dengan konsep syarat-syarat perbandingan senilai maupun perbandingan berbalik nilai, sehingga siswa bisa memberikan contoh dan bukan contoh dari perbandingan senilai maupun perbandingan berbalik nilai. Namun, masih juga terdapat siswa yang mengalami kesulitan dalam memberikan contoh. Siswa sudah paham dengan konsep perbandingan, namun siswa kurang teliti dalam menuliskan contohnya, seperti halnya dengan tidak mencantumkan keterangan pada sebuah himpunan yang dijadikan contoh. Namun masih juga terdapat siswa yang masih kesulitan dalam memberikan contoh tentang perbandingan senilai ataupun perbandingan berbalik nilai, hal ini terlihat dengan memberikan contoh perbandingan senilai maupun perbandingan berbalik nilai pada soal cerita, dimana untuk syarat elemen identitasnya tidak terpenuhi. Oleh karena itu untuk dapat menjawab pertanyaan tersebut dibutuhkan pemahaman tentang syarat perbandingan senilai ataupun perbandingan berbalik nilai dan ketelitian dalam memberikan contoh perbandingan senilai ataupun berbalik nilai. Dalam indikator ini pemahaman konsep siswa tergolong baik sesuai dengan (Gusniwati, 2015) bahwa pemahaman konsep matematika juga dapat diartikan sebagai suatu kemampuan menemukan ide abstrak dalam matematika untuk mengklasifikasikan objek-objek yang biasanya dinyatakan dalam suatu istilah kemudian dituangkan kedalam contoh dan bukan contoh, sehingga seseorang dapat memahami suatu konsep dengan jelas.

Pada indikator ke-4, yakni menyajikan konsep dalam berbagai bentuk representasi matematis, persentase untuk rata-rata nilainya yaitu $90,38 \%$ termasuk dalam kategori sangat baik. Hal ini disebabkan siswa sudah dapat menyajikan atau sudah paham tentang berbagai representasi dari perbandingan senilai maupun perbandingan berbalik 
nilai. Kesalahan yang dilakukan siswa dalam mengerjakan soal tersebut adalah dalam mengambil kesimpulan, hal ini disebabkan siswa kurang teliti dalam mengerjakan soal dan kurang teliti dalam membaca soal. Siswa sudah dapat menyajikan atau sudah paham tentang berbagai representasi dari permutasi. Namun siswa kurang tepat dalam mengambil kesimpulan. Oleh karena itu, untuk dapat menjawab pertanyaan tersebut dibutuhkan pemahaman tentang representasi dari perbandingan dan ketelitian dalam mengerjakan soal.

Pada indikator ke-5, yakni mengembangkan syarat perlu atau syarat cukup suatu konsep, persentase untuk rata-rata nilainya yaitu $14,1 \%$ termasuk dalam kategori kurang sekali. Hal ini disebabkan siswa masih mengalami kesulitan dalam melakukan pembuktian untuk menjawab syarat perlu dan cukup perbandingan senilai ataupun perbandingan berbalik nilai. Hal ini sejalan dengan pernyataan yang menyatakan bahwa pembuktian yang tepat mengandung rangkaian langkah-langkah yang logis dan argumentatif berdasarkan aturan yang berlaku di matematika untuk menunjukkan benar atau salahnya suatu ketetapan (Hanifah \& Abadi, 2018). Siswa dalam menyelesaikan soal tidak menggunakan apa yang diketahui pada soal tersebut. Siswa kurang dapat memahami maksud soal dengan baik. Akibatnya siswa siswa kurang tepat dalam menyelesaikan soal tersebut. Oleh karena itu, untuk dapat menyelesaikan soal tersebut dengan baik dibutuhkan pemahaman tentang syarat perlu atau syarat cukup suatu konsep perbandingan.
Pada indikator ke-6, yakni menggunakan, memanfaatkan, dan memilih prosedur atau operasi tertentu, persentase untuk rata-rata nilainya yaitu $73,46 \%$ termasuk ke dalam kategori baik. Hal ini disebabkan siswa sudah mampu menggunakan dan memanfaatkan apa yang diketahui pada soal untuk menyelesaikan soal tersebut, siswa juga sudah mampu menggunakan prosedur atau operasi yang dibutuhkan. Namun meskipun berada pada kategori baik, masih juga terdapat siswa yang mengalami kesulitan dalam mengerjakan soal tersebut. Saat menyelesaikan soal, siswa kurang memahami syarat suatu perbandingan senilai ataupun perbandingan berbalik nilai. Siswa kurang memahami konsep pembuktian. Siswa tidak menggunakan dan memanfaatkan apa yang sudah diketahui pada soal, siswa juga tidak menggunakan prosedur yang benar dalam pembuktian. Hal ini ditemukan bahwa siswa tidak tahu bagaimana memanfaatkan definisi untuk menyusun bukti lengkap. Oleh karena itu untuk dapat menyelesaikan soal tersebut dengan tepat, siswa harus memahami pengertian perbandingan senilai ataupun perbandingan berbalik nilai, kemudian siswa harus menggunakan dan memanfaatkan apa yang sudah diketahui pada soal, kemudian siswa harus menggunakan prosedur yang benar dalam pembuktian perbandingan.

Pada indikator ke-7, yakni mengaplikasikan konsep atau algoritma pemecahan masalah, persentase untuk rata-rata nilainya yaitu $41,15 \%$ termasuk dalam kategori cukup. Hal ini disebabkan siswa sudah mampu mengaplikasikan sebuah konsep pembuktian perban- 
dingan senilai maupun perbandingan berbalik nilai pada soal tersebut. Siswa sudah mampu menerapkan penalaran logisnya melalui apa yang diketahui pada soal tersebut, sehingga teori pada perbandingan dapat digunakan untuk menyelesaikan soal tersebut dengan tepat. Namun meskipun berada pada kategori cukup, masih juga terdapat siswa yang mengalami kesulitan dalam mengerjakan soal tersebut. Dalam menyelesaikan soal siswa belum mengaplikasikan konsep pembuktian perbandingan, siswa kurang memahami konsep pembuktian perbandingan. Siswa dalam membuktikan tidak menggunakan apa yang diketahui pada soal, sehingga siswa kurang memahami konsep. Kemampuan pemahaman konsep matematis dalam merepresentasikan konsep sulit dan kurang antusias (Agustini \& Pujiastuti, 2020). Siswa tidak memahami dan tidak dapat menyatakan definisi. Oleh karena itu, untuk dapat menyelesaikan soal tersebut dengan tepat, maka siswa harus mampu menyatakan definisi perbandingan, kemudian siswa memahami konsep langkah-langkah pembuktian pada perbandingan, lalu mengaplikasikan konsep tersebut dalam menyelesaikan soal-soal perbandingan (Rojak, 2017). Pemahaman konsep dapat meningkat dengan mengimplementasikan model pembelajaran (N. Afifah, 2019)

\section{PENUTUP}

Berdasarkan analisis data, hasil penelitian dan pembahasan yang telah dilakukan pada bab sebelumnya, diperoleh kesimpulan penelitian bahwa persentase pemahaman konsep siswa dalam menyelesaikan soal perbandingan pada indikator menyatakan ulang sebuah konsep 67,18\%, pada indikator mengklasifikasikan objek-objek menurut sifat-sifat tertentu 37,69\%, pada indikator memberikan contoh dan non contoh dari konsep 99,04\%, pada indikator menyajikan konsep dalam berbagai bentuk representasi matematis $90,38 \%$, pada indikator mengembangkan syarat perlu atau syarat cukup suatu konsep $14,1 \%$, pada indikator menggunakan, memanfaatkan, dan memilih prosedur atau operasi tertentu $73,46 \%$, dan pada indikator mengaplikasikan konsep atau algoritma pemecahan masalah 41,15\%. Kesalahan-kesalahan yang dilakukan siswa dalam menyelesaikan soal perbandingan yaitu kesalahan konsep, kesalahan dalam memahami gagasan abstrak, kesalahan data yaitu mengabaikan data penting yang diberikan pada soal, kesalahan menggunakan logika untuk menarik kesimpulan, kesalahan menggunakan definisi atau teorema, penyelesaian tidak diperiksa kembali dan kesalahan strategi. Penyebab siswa melakukan kesalahan dalam menyelesaikan soal perbandingan yaitu siswa kurang teliti dalam membaca soal, siswa kurang mampu memahami soal-soal abstrak, siswa kurang paham dengan konsep pembuktian, siswa kurang paham bagaimana cara mengawali sebuah pembuktian, siswa kesulitan dalam memahami dan mengingat definisi-definisi pada konsep pembuktian, siswa kesulitan dalam memanfaatkan definisi dalam menyusun sebuah pembuktian dan siswa kurang percaya diri dalam menjawab sebuah soal. 


\section{DAFTAR PUSTAKA}

Afifah, I. K. A., \& Sopiany, H. N. (2017). Analisis Kemampuan Pemahaman Konsep Matematis Sisawa SMP Dalam Pembelajaran Matematika Berbasis Kontekstual. Prosiding Seminar Nasional Matematika Dan Pendidikan Matematika (SESIOMADIKA) 2017, 452-459. http://sesiomadika. 890m.com/Prosiding/66IkaAfifahSESIOMADIKA-2017

Afifah, N. (2019). Penerapan Model Pembelajaran Pencapaian Konsep Untuk Meningkatkan Pemahaman Konsep. Numeracy Journal, 6(2). file://C:/Users/DemoR/OneDrive/ Documents/Downloads/480-

Article Text-844-1-1020200313.pdf

Agustini, D., \& Pujiastuti, H. (2020). Analisis Kesulitan Siswa Berdasarkan Kemampuan Pemahaman Matematis dalam Menyelesaikan Soal Cerita Pada Materi SPLDV. Media Pendidikan Matematika, 8(1), $18 . \quad$ https:// doi.org/10.33394/mpm.v8i1.2568

Fadlilah, N. (2015). Pemahaman Konsep Siswa Pada Materi Volume Prisma Dengan Pendekatan Pendidikan Matematika Realistik Indonesia (Pmri). Jurnal Pendidikan Matematika, 8(2). https://doi.org/10.22342/jpm.8.2.1 864.20-32

Gusniwati, M. (2015). Pengaruh Kecerdasan Emosional dan Minat Belajar terhadap Penguasaan Konsep Matematika Siswa SMAN di Kecamatan Kebon Jeruk. Formatif: Jurnal Ilmiah Pendidikan MIPA, 5(1), 26-41. https://doi.org/ 10.30998/formatif.v5i1.165

Hanifah, \& Abadi, A. P. (2018). Analisis Pemahaman Konsep Matematika
Mahasiswa dalam Menyelesaikan Soal Teori Grup kemampuan yang mengharapkan siswa mahasiswa pada program sarjana dan mahasiswa yang akan melanjutkan studi teori-teori dasar dan pembuktian menyebabkan mahasiswa senantiasa. Jurnal of Medives, 2(2), 235-244.

Karunia, E. P., \& Mulyono. (2016). Analisis kemampuan pemahaman konsep siswa kelas VII berdasarkan gaya belajar dalam model knisley. Prosiding Seminar Nasional Matematika, 339. https://doi.org/10.1016/j.ijmecsci.2 014.08.026

Nastiti, F. N. F., \& Syaifudin, A. H. (2020). Hubungan Pemahaman Konsep Matematis terhadap Hasil Belajar Siswa Kelas VIII SMP N 1 Plosoklaten pada Materi Lingkaran. Jurnal Pendidikan Matematika, 4(1), 8-15. http://phi.unbari.ac.id/index.php/ph i/article/view/80

Purnomo, B. (2018). Pemahaman Konsep Matematika Siswa Melalui Model Pembelajaran Air (Auditory , Intellectualy, Repetition) Dan Model Pembelajaran Course Review Horay Pada Siswa Kelas Xi Ipa Sma Budi Utomo Jombang. Soulmath, 6(1), 1. https://doi.org/ 10.25139/sm.v6i1.376

Rojak, A. (2017). Analisis pemahaman konsep pada materi perbandingan siswa smp.

Tanjung, D. S., \& Herawati, S. (2020). Analisis Pemahaman Konsep Matematika Ditinjau Dari Kemampuan Metakognisi Siswa Kelas Viii Smpn 12 Padang. ... Fakultas Keguruan Dan ..., 2-4. https://ejurnal.bunghatta.ac.id/inde x.php/JFKIP/article/view/17382 